\title{
Spatiotemporal Variability Analysis of Groundwater Level for Water Resources Development and Management in Northern Punjab, India
}

\author{
Krishan $\mathbf{G}^{1,2 *}$, Lohani $\mathrm{AK}^{1}$, Rao MS ${ }^{1}$, Kumar $\mathbf{S}^{1}$ and Takshi $\mathrm{KS}^{3}$
}

${ }^{1}$ National Institute of Hydrology, Roorkee, Uttarakhand, India

${ }^{2}$ IGB Groundwater Resilience Project, British Geological Survey, United Kingdom

3/rrigation Department, Punjab, Chandigarh, India

\begin{abstract}
The present study was conducted for investigating spatiotemporal variations in the groundwater levels recorded on monthly basis during 2006-2013 in northern parts of Punjab, India, comprising of 3 districts viz., Amritsar, Gurdaspur and Tarn Taran. The entire data of 8 years was divided into three seasons: pre-monsoon (February-May), monsoon (June-September) and post monsoon (October-January). It was observed in Gurdaspur district that the groundwater level depths increased in monsoon seasons with an overall variation range of $0.22 \%$ to $9.67 \%$. In Amritsar district, in monsoon season, the highest increase of $6.22 \%$ in groundwater level depth was found in the Ajanala block and least increase of $0.36 \%$ in Tarshika, while in Tarn Taran district, the highest increase of $3.87 \%$ in groundwater level depth was found in the Noushera Pannua block and least increase of $0.95 \%$ was found in Tarn Taran block. The groundwater level decreased in the range of $0.15 \mathrm{~m}$ to $1.80 \mathrm{~m}$ with an annual decrease in groundwater level in the range of $0.02 \mathrm{~m}$ to $0.23 \mathrm{~m}$. The increase in groundwater level depth in monsoon seasons was found due to extreme usage in irrigation for rice crop and the recharging of aquifers is not speedy. However, it has also been observed that the groundwater level rises again in the post monsoon season due to the groundwater resilience of the aquifers. Besides this, the extensive recharge in the area is observed by Ravi and Beas rivers because of perennial nature. A regular monitoring of groundwater in different seasons of the year and its spatiotemporal analysis is required for adopting the appropriate management practices including conjunctive use of surface and groundwater for maintaining its sustainability.
\end{abstract}

Keywords: Groundwater level; Spatial and temporal variations; trend; Fluctuations; Northern Punjab

\section{Introduction}

The present trend of ever-increasing human and livestock populations, change in cropping pattern and polluting surface water bodies leading to heavy usage and consequential depletion of fresh water resources in all over the World and the groundwater regime may not be sustainable for more than a few decades. Estimates of ground water resources of India as on 2011 shows that about 245 billion cubic meter (BCM) fresh water resource is abstracted annually of which $91 \%$ is used in agriculture and remaining $9 \%$ is used in domestic and industrial purpose [1]. The use of groundwater to agriculture is more as compared to other uses leading to groundwater depletion. Such patterns of steady groundwater decline are witnessed in many parts of the country, particularly Punjab [2,3] which occupies more than twice of the national average (40\%) of the available cultivated land. The annual rate of groundwater level decline found to increase by about $80 \%$ during 1980-2005 [4] and which is projected to fall by about 21 meter in $2 / 3^{\text {rd }}$ area of central Punjab during next 2 decades [5].

In Punjab, most of the studies were carried out focusing on the groundwater level and quality in Bist-Doab, Punjab [6-19] but no such study was carried out in the northern area (Majha, Vern). This area comprises of the modern districts of Amritsar, Gurdaspur and Tarn Taran. The cultivable area in all these 3 districts is more than $80 \%$. The main problem of the Amritsar and Tarn Taran districts is the over-exploitation of groundwater and in Gurdaspur district the groundwater is depleting at an alarming level and the stage of groundwater development is more than $100 \%$ (Table 1).

The present study was carried out to analyze the monthly groundwater level monitored during 2006-13 for assessing the spatiotemporal variations. This study will provide useful input to the engineers and water resource planners for development and management of surface and groundwater resources.

\section{Study Area}

The northern Punjab also called "Majha" (means "central" or "that lies in the middle" of the historical Punjab) is the region of Punjab bounded by rivers Beas and Sutlej on the right banks extending upto river Jhelum at its north most part. Majha includes a considerable portion of the Bari Doab (the region between the rivers Beas and Ravi) and the Rechna Doab (the region between the rivers Ravi and Chenab), and a smaller portion of the Jech Doab region (the region between the rivers Jhelum and Chenab). The northern Punjab includes 3 districts Amritsar, Gurdaspur and Tarn Taran and the details of the districts are given in (Table 1) $[6-8,29,30]$.

\section{Amritsar}

Amritsar comes under tropical steppe, semi-arid and hot climate with normal annual rainfall $680 \mathrm{~mm}$ and over 31 rainy days. The south west monsoon contributes $75 \%$ of the total rainfall [6]. Soils in the western part of the district are coarse loamy, calcareous soils, where as in the central part of the district soils are fine loamy, calcareous and are well drained. As per report of [6] depth to water level in the district ranges from 6.41 to $22.98 \mathrm{mbgl}$ (meter below ground level) during pre monsoon period and between 4.91 to $22.98 \mathrm{mbgl}$ during post monsoon

*Corresponding author: Krishan G, National Institute of Hydrology, Roorkee, Uttarakhand, India, Tel: +91-1332-272108; E-mail: drgopal.krishan@gmail.com

Received December 31, 2014; Accepted February 22, 2015; Published February 27, 2015

Citation: Krishan G, Lohani AK, Rao MS, Kumar S, Takshi KS (2015) Spatiotemporal Variability Analysis of Groundwater Level for Water Resources Development and Management in Northern Punjab, India. J Environ Anal Toxicol 5: 279. doi:10.4172/2161-0525.1000279

Copyright: ( 2015 Krishan G, et al. This is an open-access article distributed under the terms of the Creative Commons Attribution License, which permits unrestricted use, distribution, and reproduction in any medium, provided the original author and source are credited. 


\begin{tabular}{|c|c|c|c|c|}
\hline $\begin{array}{c}\text { Serial } \\
\text { No. }\end{array}$ & Parameters & Amritsar & Gurdaspur & Tarn Taran \\
\hline 1 & Latitude (N) & $31^{\circ} 28^{\prime}-32^{\circ} 15^{\prime}$ & $31^{\circ} 36^{\prime}-32^{\circ} 34^{\prime}$ & $30^{\circ} 05^{\prime}-31^{\circ} 30^{\prime}$ \\
\hline 2 & Longitude (E) & $74^{\circ} 29^{\prime}-75^{\circ} 24^{\prime}$ & $74^{\circ} 56^{\prime}-75^{\circ} 24^{\prime}$ & $74^{\circ} 30^{\prime}-75^{\circ} 15^{\prime}$ \\
\hline 3 & $\begin{array}{l}\text { Elevation from mean } \\
\text { sea level (MSL) (m) }\end{array}$ & 230 & $305-381$ & 227 \\
\hline 4 & Area (Sq. km) & 5056 & 3513 & 2449 \\
\hline 5 & $\begin{array}{l}\text { Population(as per } \\
\text { 2011census) }\end{array}$ & $24,90,891$ & $22,99,026$ & $11,20,070$ \\
\hline 6 & $\begin{array}{c}\text { Population growth from } \\
2001 \text { to } 2011(\%)\end{array}$ & 15.48 & 9.30 & 19.28 \\
\hline 7 & $\begin{array}{l}\text { Normal Annual Rainfall } \\
(\mathrm{mm})\end{array}$ & 680 & 1013 & 545 \\
\hline 8 & $\begin{array}{l}\text { Normal Monsoon } \\
\text { Rainfall }(\mathrm{mm})\end{array}$ & 510 & 890 & 382 \\
\hline 9 & Normal Rainy days & 31 & 48 & 30 \\
\hline 10 & $\begin{array}{l}\text { Temperature (Mean } \\
\text { Minimum) }\left({ }^{\circ} \mathrm{C}\right)\end{array}$ & $\begin{array}{c}5.1 \\
\text { (January) }\end{array}$ & $\begin{array}{c}5.0 \\
\text { (January) }\end{array}$ & $\begin{array}{c}4.5 \\
\text { (January) }\end{array}$ \\
\hline 11 & $\begin{array}{l}\text { Temperature (Mean } \\
\text { Maximum }\left({ }^{\circ} \mathrm{C}\right)\end{array}$ & $\begin{array}{c}41.1 \\
\text { (May \& June) }\end{array}$ & $\begin{array}{c}44.0 \\
\text { (May \& June) }\end{array}$ & $\begin{array}{c}40.5 \\
\text { (May \& June) }\end{array}$ \\
\hline 12 & Soil type & $\begin{array}{l}\text { Loamy sand, } \\
\text { sandy loam }\end{array}$ & $\begin{array}{l}\text { Reddish } \\
\text { chestnut \& } \\
\text { tropical arid }\end{array}$ & Arid \\
\hline 13 & $\begin{array}{l}\text { Depth water level (pre } \\
\text { monsoon) (mbgl-meter } \\
\text { below ground level) }\end{array}$ & $6.41-22.98$ & $2.39-18.93$ & $7.97-21$ \\
\hline 14 & $\begin{array}{l}\text { Depth water level (post } \\
\text { monsoon) (mbgl-meter } \\
\text { below ground level) }\end{array}$ & $4.91-22.98$ & $1.70-16.76$ & 8.23- 21.5 \\
\hline 15 & $\begin{array}{l}\text { Rate of decline of } \\
\text { groundwater }(\mathrm{m} / \mathrm{yr})\end{array}$ & 0.50 & 0.35 & 0.29 \\
\hline 16 & Net area sown (Sq. km) & 2220 & 2850 & 2100 \\
\hline 17 & $\begin{array}{c}\text { Percent Agricultural } \\
\text { Area }\end{array}$ & 84 & 81 & 86 \\
\hline 18 & $\begin{array}{c}\text { Net Annual } \\
\text { Groundwater } \\
\text { availability (ham) }\end{array}$ & 129956 & 185256 & 116164 \\
\hline 19 & $\begin{array}{l}\text { Existing gross ground } \\
\text { water draft (ham) }\end{array}$ & 190691 & 197697 & 182284 \\
\hline 20 & $\begin{array}{l}\text { Stage of Ground Water } \\
\text { Development (\%) }\end{array}$ & 147 & 107 & 160. \\
\hline 21 & $\begin{array}{l}\text { Water Type (Shallow } \\
\text { Groundwater) }\end{array}$ & $\mathrm{CaMg}-\mathrm{HCO}_{3}$ & $\mathrm{CaMg}-\mathrm{HCO}_{3}$ & $\mathrm{CaMg}-\mathrm{HCO}_{3}$ \\
\hline 22 & $\mathrm{EC}(\mu \mathrm{S} / \mathrm{cm})$ & $375-875$ & $235-1640$ & $355-1200$ \\
\hline 23 & Water course & $\begin{array}{l}\text { Upper Bari } \\
\text { Doab canal, } \\
\text { Beas River }\end{array}$ & $\begin{array}{c}\text { Rivers Beas \& } \\
\text { Ravi }\end{array}$ & $\begin{array}{l}\text { Upper Bari } \\
\text { Doab canal }\end{array}$ \\
\hline 24 & Major crops & Rice, Wheat & Wheat, rice & Wheat, rice, \\
\hline
\end{tabular}

period. Groundwater is $\mathrm{CaMg}-\mathrm{HCO}_{3}$ type and $\mathrm{EC}$ is found less than $1000 \mu \mathrm{S} / \mathrm{cm}$ at $\left.25^{\circ} \mathrm{C}\right)$. All the blocks come under the category "overexploited" [6].

\section{Gurdaspur}

The climate of the district is tropical type with normal annual rainfall of the area is $1113 \mathrm{~mm}$ out of which $80 \%$ is contributed by south western monsoon [8]. The district can be divided into three geo-morphological types-hilly area, piedmont zone and alluvial plain. Water levels of the area in pre-monsoon period varies from 2.39 (Khani Khui) to $18.93 \mathrm{mbgl}$ with the shallowest water level in the eastern and north-eastern portion of Gurdaspur town and the deepest water levels are around Shri Hargobindpur and Fatehgarh Churrian. In the same way the post monsoon water levels are variable from $1.70 \mathrm{mbgl}$ (Behram pur) to $16.76 \mathrm{mbgl}$ (Sri Hargobindpur). Groundwater is $\mathrm{CaMg}-\mathrm{HCO}_{3}$ type and EC ranges from 235 to $1640 \mu \mathrm{S} / \mathrm{cm}$ at $25^{\circ} \mathrm{C}$ [8].

\section{Tarn taran}

Tarn Taran comes under tropical steppe, semi-arid and hot with normal annual rainfall of the district is $545 \mathrm{~mm}$ with 30 rainy days. Out of the total, south west monsoon contributes $74 \%$. Saline and alkaline soils occur in the district. Water levels in pre-monsoon and postmonsoons are found 7.97-21 m (bgl) and 8.23-21.50 mbgl, respectively [7]. Groundwater is $\mathrm{CaMg}-\mathrm{HCO}_{3}$ type and $\mathrm{EC}$ ranges from 355 to 1200 $\mu \mathrm{S} / \mathrm{cm}$ at $25^{\circ} \mathrm{C}$ [7].

\section{Materials and Methods}

The monthly water level data was measured in shallow piezometers/ bore holes $(60 \mathrm{~m})$ developed by Punjab Water Resources and Environment Directorate, Chandigarh in 4 blocks (Ajnala, Majitha, Rayya and Tarsika) of Amritsar district; 8 blocks (Batala, Dera Baba Nanak, Dina Nagar, Gurdaspur, Fatehgarh Churian, Kahnuwan, Kalanaur and Sri Hargovindpur) of Gurdaspur district and 5 blocks (Bhikhiwind, Gandiwind, Khadur Sahib, Naushera Pannua and Tarn Taran) of Tarn Taran district using the water level recorders. The locations map is given in (Figure 1). Across these districts, detailed water level data sets has been generated sequentially on monthly basis over the last 8 years between January 2006 to December 2013 for assessing the patterns of groundwater level trends. The entire data was divided into 3 seasons as pre-monsoon (February-May), monsoon (June-September) and post monsoon (October-January). The data processing was done to remove the erroneous data before statistical analysis. The erroneous values were rectified.

\section{Results and Discussion}

The average water level and its spatial distribution are shown in (Figures 2 and 3), respectively. The average water level (bgl) during 2006-2013 in Amritsar, Gurdaspur and Tarn Taran was 10.04 m, 6.64 $\mathrm{m}$ and $14.83 \mathrm{~m}$ below ground, respectively. In Gurdaspur district, the water level is very high followed by Amritsar with an extreme low in Tarn Taran district. The observed dataset point towards the declining and fluctuating groundwater levels in the Majha Region of Punjab during 2006-2013. The maximum decline to $3.33 \mathrm{~m}$ level was found in Tarn Taran district, which is followed by a decline of $1.37 \mathrm{~m}$ in Amritsar district and least decline to the tune of $1.08 \mathrm{~m}$ was found in Gurdaspur district. Analysis of water table depth has shown that the groundwater depth shows variation from 8.20 to $11.25 \mathrm{mbgl}$ in Amritsar, 5.75 to $7.26 \mathrm{mbgl}$ in Gurdaspur and 13.49 to $15.50 \mathrm{mbgl}$ in Tarn Taran. The increased depth of water level was found in June and July months in all the blocks, due to extreme usage in irrigation for rice crop. Besides this, the least depth of water level was found in the months of FebruaryMarch due to the recharge in post monsoon season.

The continuous rotation of wheat and paddy cropping pattern, degraded and depleted soil and water and the extensive water usage in Punjab resulted in falling groundwater levels. Rodell et al. [3] have also reported irrigation as a major cause for high water level depletion. Similar results are also obtained in the detailed study carried out in Bist Doab region by Krishan et al. $[13,14]$. In the study, the automatic water level recorders were installed in the 6 piezometers and a high resolution data was obtained. It was observed that the water level depth increased due to the more use of groundwater during Kharif season and the water level depth decreased during the pre-monsoon period.

As evident from (Table 2 and Figure 4) that the groundwater level depths were increased in monsoon seasons with an overall variation range of $0.22 \%$ to $9.67 \%$, which were observed in Gurdaspur district. In Amritsar district, in monsoon season, the highest increase of 


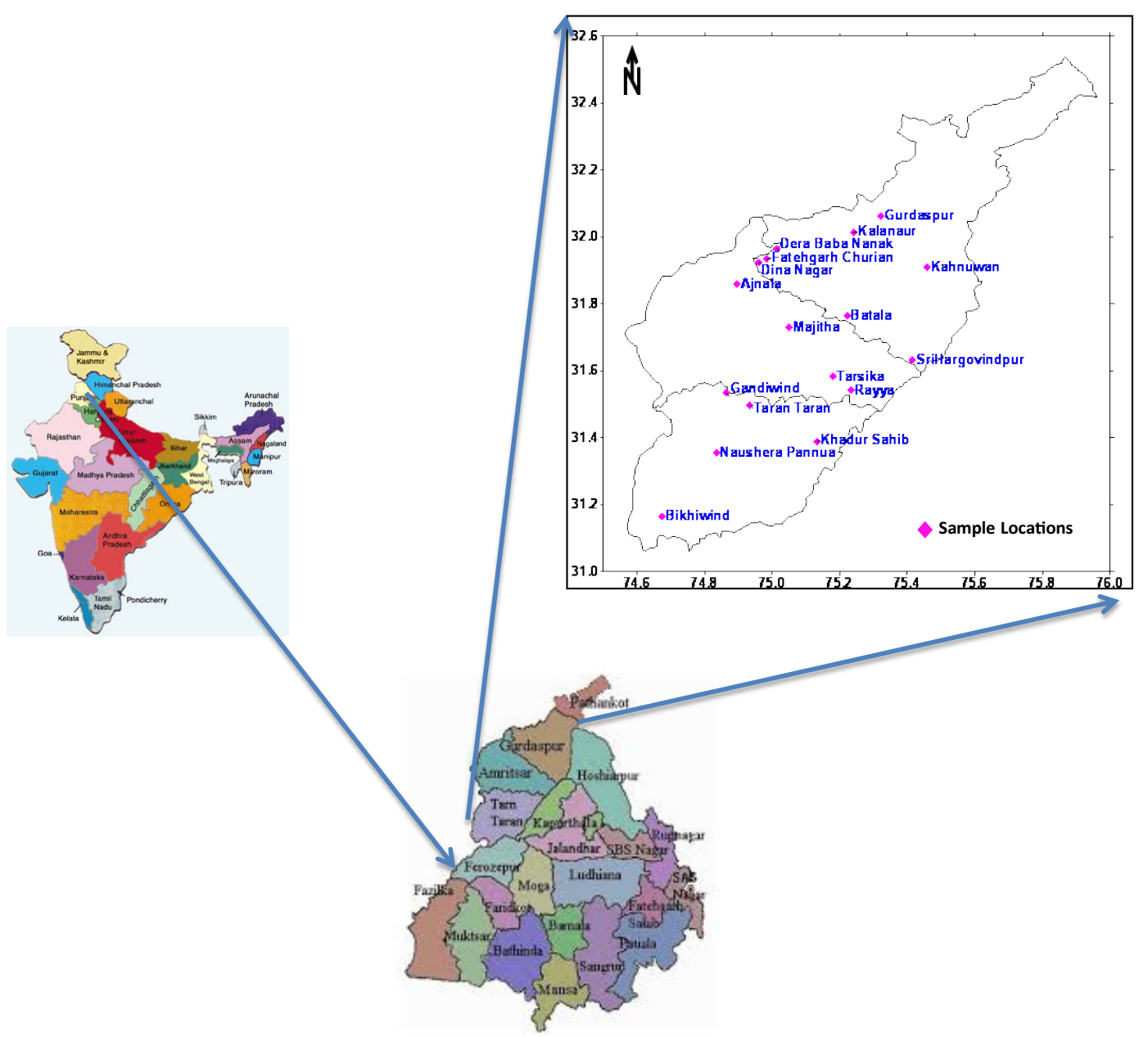

Figure 1: Groundwater monitoring points of northern Punjab.

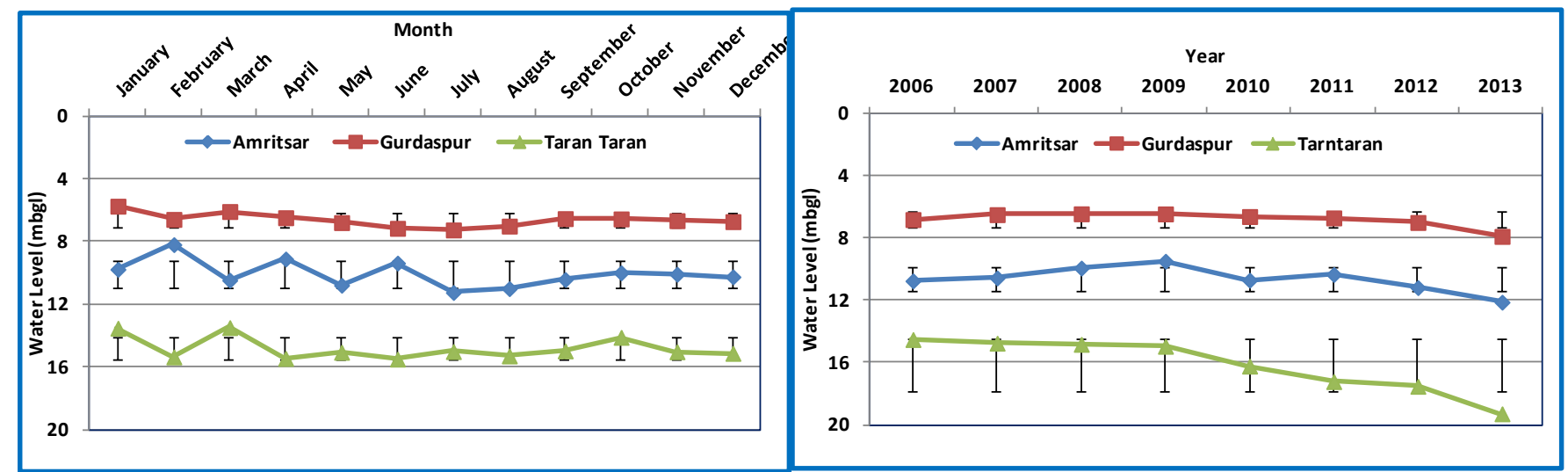

Figure 2: Monthly and Yearly Groundwater level (m bgl) of northern Punjab.

$6.22 \%$ in groundwater level depth was found in the Ajanala block and least increase of $0.36 \%$ in Tarshika, while in Tarn Taran district, the highest increase of $3.87 \%$ in groundwater level depth was found in the Noushera Pannua block and least increase of $0.95 \%$ in Tarn Taran block. However, it has also been observed that the groundwater level rises again in the post monsoon season which shows the resilience nature of the aquifers and same has been reported in an extensive study carried out in Bist-Doab, Punjab, India by Lapworth et al. [10]. Besides this, the extensive recharge in the area is observed by Ravi and Beas rivers because of perennial nature in the study area.

The annual fluctuation pattern of the groundwater of the study area 


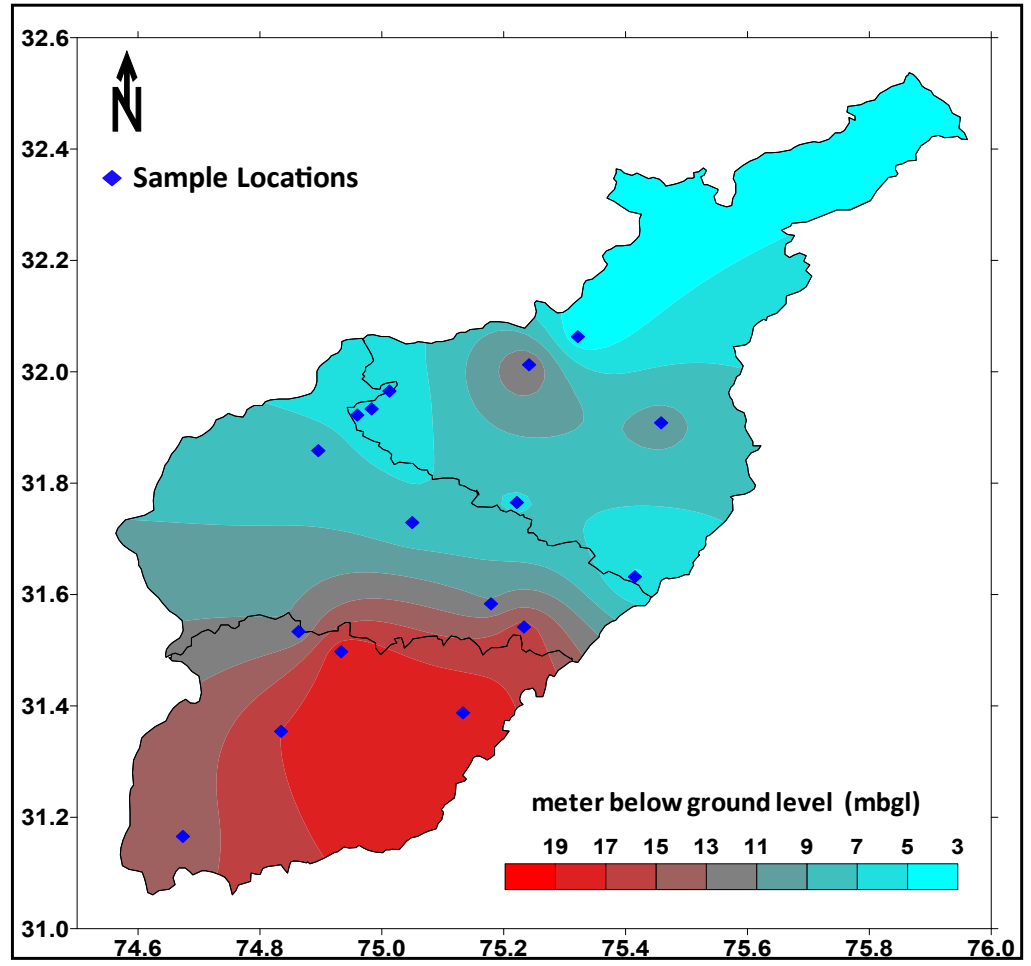

Figure 3: Average Groundwater level ( $\mathrm{m}$ bgl) across all months of northern Punjab.

\begin{tabular}{|c|c|c|c|c|c|c|c|c|c|c|c|c|c|}
\hline \multirow{3}{*}{ Distt. } & \multirow{3}{*}{$\begin{array}{l}\text { Locations/ } \\
\text { Blocks }\end{array}$} & \multicolumn{12}{|c|}{ Groundwater level (m bgl) } \\
\hline & & \multicolumn{4}{|c|}{ Pre-monsoon (Feb -May) } & \multicolumn{4}{|c|}{ Monsoon (Jun -Sep) } & \multicolumn{4}{|c|}{ Post-monsoon (Oct -Jan) } \\
\hline & & Min & $\operatorname{Max}$ & Av & SD & Min & $\operatorname{Max}$ & Av & SD & Min & $\operatorname{Max}$ & Av & SD \\
\hline \multirow{4}{*}{$\begin{array}{l}\text { Amrit } \\
\text { sar }\end{array}$} & Ajnala & 6.86 & 9.70 & 7.67 & 0.57 & 6.60 & 10.75 & 8.14 & 0.78 & 6.18 & 8.70 & 7.60 & 0.61 \\
\hline & Majitha & 5.20 & 10.20 & 7.28 & 1.25 & 6.00 & 11.25 & 7.77 & 1.36 & 5.60 & 9.66 & 7.37 & 1.34 \\
\hline & Rayya & 13.67 & 18.10 & 15.76 & 0.90 & 14.68 & 19.15 & 16.28 & 0.93 & 14.21 & 17.04 & 15.72 & 0.79 \\
\hline & Tarsika & 8.76 & 13.00 & 11.19 & 1.14 & 9.00 & 14.15 & 11.23 & 1.32 & 9.10 & 12.84 & 11.17 & 1.25 \\
\hline \multirow{8}{*}{$\begin{array}{c}\text { Gurdas } \\
\text { pur }\end{array}$} & Batala & 5.50 & 9.20 & 6.60 & 0.88 & 5.00 & 9.10 & 7.24 & 0.96 & 4.70 & 8.40 & 6.35 & 1.02 \\
\hline & Dera Baba Nanak & 4.47 & 7.60 & 5.07 & 1.02 & 3.20 & 7.40 & 5.32 & 0.97 & 4.10 & 7.30 & 4.93 & 1.01 \\
\hline & Dina Nagar & 5.53 & 8.15 & 6.18 & 0.65 & 5.40 & 7.65 & 6.60 & 0.62 & 5.20 & 8.00 & 6.10 & 0.69 \\
\hline & Gurdaspur & 2.73 & 4.75 & 3.32 & 0.46 & 2.35 & 4.30 & 3.41 & 0.57 & 2.65 & 4.60 & 3.28 & 0.52 \\
\hline & Fatehgarh Churian & 4.30 & 6.85 & 4.92 & 0.60 & 4.00 & 6.50 & 5.29 & 0.66 & 3.90 & 6.70 & 4.83 & 0.80 \\
\hline & Kahnuwan & 8.97 & 10.75 & 9.89 & 0.46 & 9.27 & 10.77 & 10.04 & 0.40 & 9.07 & 10.90 & 9.76 & 0.46 \\
\hline & Kalanaur & 12.45 & 15.70 & 13.08 & 0.68 & 12.48 & 15.40 & 13.42 & 0.76 & 12.35 & 14.75 & 13.02 & 0.69 \\
\hline & $\begin{array}{c}\text { SriHar } \\
\text { govindpur }\end{array}$ & 4.06 & 6.20 & 4.82 & 0.49 & 3.96 & 5.66 & 4.83 & 0.38 & 3.96 & 5.16 & 4.57 & 0.35 \\
\hline \multirow{5}{*}{$\begin{array}{l}\text { Tarn } \\
\text { taran }\end{array}$} & Bikhiwind & 11.56 & 17.40 & 13.87 & 2.01 & 12.25 & 17.63 & 14.25 & 1.84 & 11.80 & 16.76 & 13.90 & 1.81 \\
\hline & Gandiwind & 7.95 & 13.05 & 11.08 & 1.80 & 8.07 & 13.52 & 11.38 & 1.80 & 8.40 & 13.96 & 12.04 & 1.56 \\
\hline & Khadur Sahib & 16.00 & 20.20 & 18.14 & 0.99 & 16.70 & 21.20 & 18.76 & 1.16 & 16.30 & 19.41 & 18.07 & 0.94 \\
\hline & Naushera Pannua & 14.20 & 20.40 & 16.78 & 2.37 & 14.00 & 21.40 & 17.43 & 2.42 & 14.10 & 19.94 & 16.87 & 2.23 \\
\hline & Taran Taran & 17.10 & 21.15 & 18.55 & 1.12 & 16.68 & 21.58 & 18.72 & 1.33 & 16.51 & 21.02 & 18.42 & 1.16 \\
\hline
\end{tabular}

Table 2: Season wise variations in Groundwater level ( $\mathrm{m}$ bgl) in northern Punjab (2006-13).

is shown in (Figure 5). In Amritsar, the groundwater level depth was increasing in 3 blocks -Ajnala, Tarshika and Rayya from 2006 to 2013 but in Majiha block the groundwater depth decreased in year 2013. The groundwater level found decreased by $1 \mathrm{~m}$ to $1.80 \mathrm{~m}$ during these 8 years with an annual decrease of $0.13 \mathrm{~m}$ to $0.23 \mathrm{~m}$.

In Gudaspur, the groundwater level depth was increasing in 5 blocks -Batala, Gurdaspur, Fatehgarh, Kahnuwan and Kalanaur from 2006 to 2013 in the range of $0.15 \mathrm{~m}$ to $0.65 \mathrm{~m}$ with an annual decrease in the groundwater level in the range of $0.02 \mathrm{~m}$ to $0.08 \mathrm{~m}$. But in 3 blocksDera Baba Nanak, Dina Nagar and Sri Hargobindpur the groundwater level rise was found in the range of $0.05 \mathrm{~m}$ to $0.49 \mathrm{~m}$ with an annual increase of $0.01 \mathrm{~m}$ to $0.06 \mathrm{~m}$.

In Tarn Taran, the groundwater level depth was increasing in 4 blocks -Bhikhiwind, Khadur Sahib, Noushera Pannua and Tarn Taran from 2006 to 2013 in the range of $0.73 \mathrm{~m}$ to $1.52 \mathrm{~m}$ with an annual decrease in the groundwater level in the range of $0.06 \mathrm{~m}$ to $0.17 \mathrm{~m}$. But 
Citation: Krishan G, Lohani AK, Rao MS, Kumar S, Takshi KS (2015) Spatiotemporal Variability Analysis of Groundwater Level for Water Resources Development and Management in Northern Punjab, India. J Environ Anal Toxicol 5: 279. doi:10.4172/2161-0525.1000279

Page 5 of 6

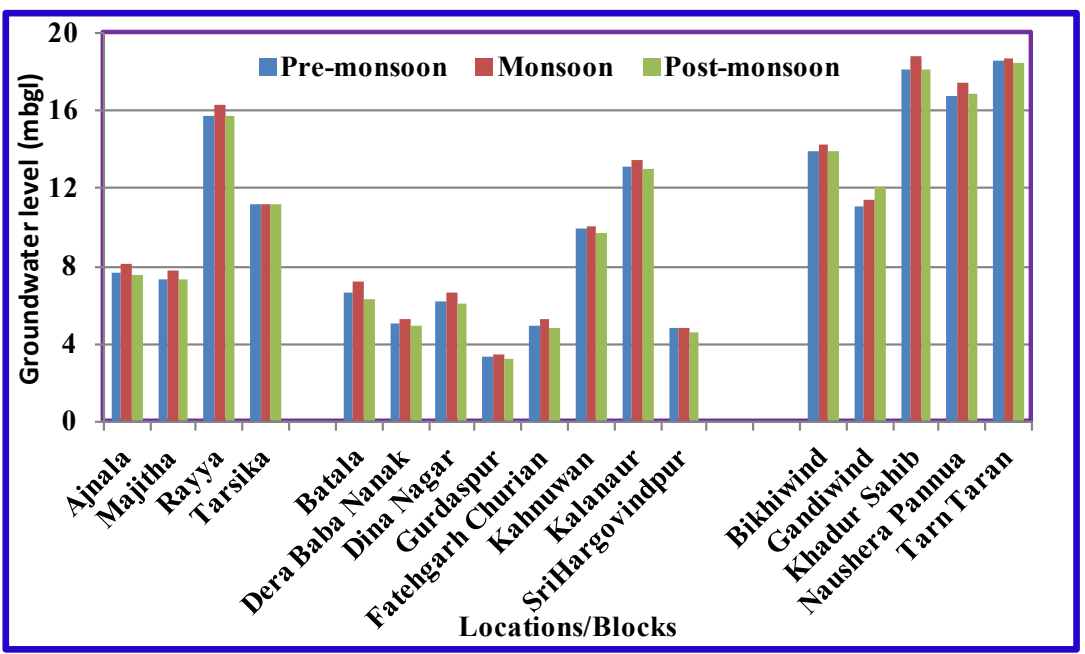

Figure 4: Season wise average groundwater level ( $\mathrm{m}$ bgl) in northern Punjab (2006-13).
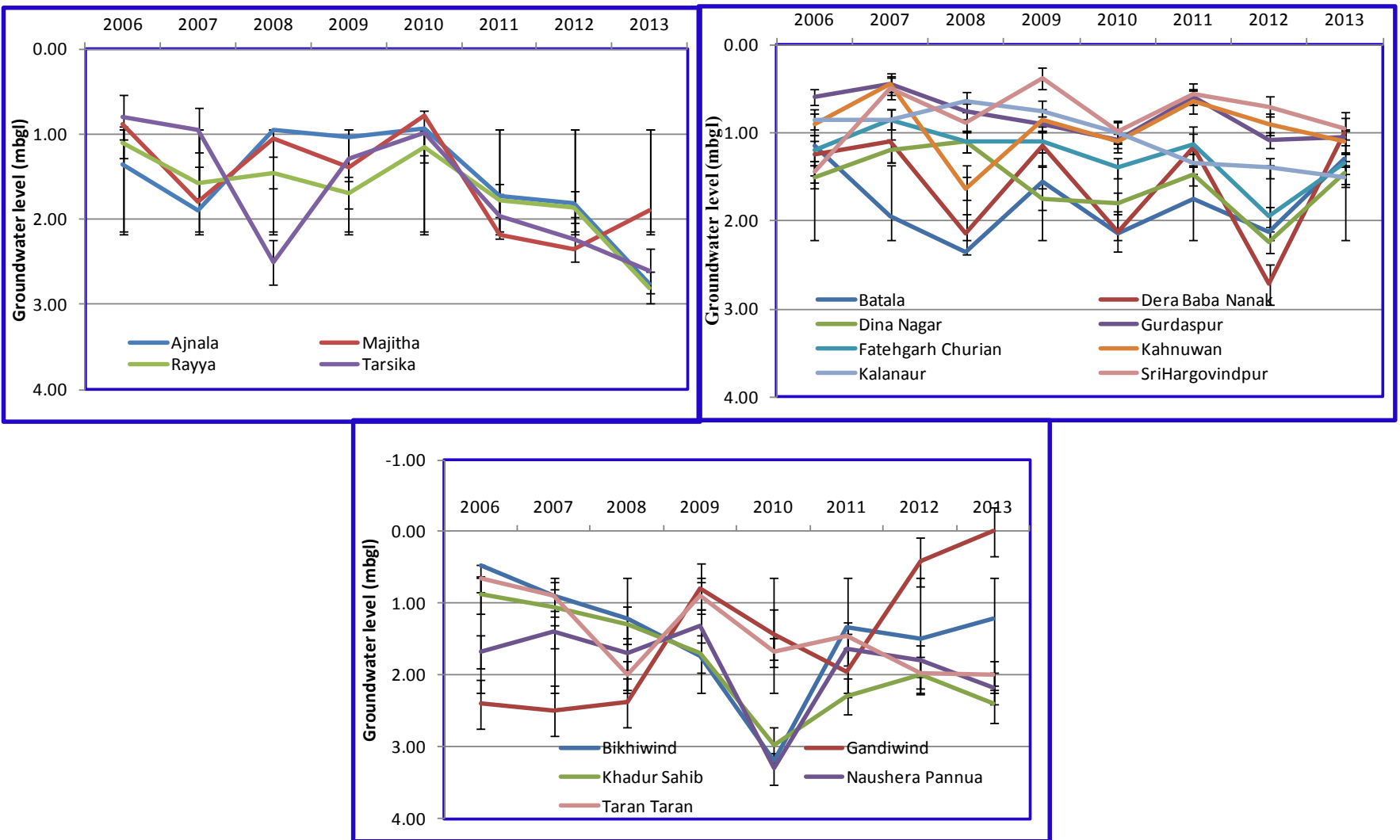

Figure 5: Annual fluctuation pattern of groundwater level ( $\mathrm{m} \mathrm{bgl}$ ) in northern Punjab (2006-13).

in Gandhiwind block the groundwater level rise was found to the tune of $2.40 \mathrm{~m}$ with an annual increase of $0.30 \mathrm{~m}$.

The difference in decline in phreatic water levels may be due to local aquifers or variation in the aquifer structures and availability of groundwater [2,9].

For water resource management, drainage also has an important role to control ground water table and the design of horizontal and vertical drainage. The layout, depth and spacing of the drains are often done using subsurface drainage equations with parameters like drain depth, depth of the water table, soil depth, hydraulic conductivity of the soil and drain discharge. Selecting a proper drainage system always has been discussed in agricultural or other fields [19-21]. The analytical solutions improved the accuracy of predicting the dissipation of pore water pressure and the associated settlement which depends on soil characteristics parameters [22-26]. Gallichand presented numerical 
Citation: Krishan G, Lohani AK, Rao MS, Kumar S, Takshi KS (2015) Spatiotemporal Variability Analysis of Groundwater Level for Water Resources Development and Management in Northern Punjab, India. J Environ Anal Toxicol 5: 279. doi:10.4172/2161-0525.1000279

simulations of steady-state subsurface drainage with vertically decreasing hydraulic conductivity [27]. The results presented could be used to estimate the error on water table depth resulting from ignoring the vertical variations of hydraulic conductivity. Hunt discussed about flow to vertical and non-vertical wells in leaky aquifers [28].

\section{Conclusions}

The study conducted for investigating spatiotemporal variations in the groundwater levels recorded during 2006-2013 in northern parts of Punjab, India showed that the groundwater level decreased from $0.15 \mathrm{~m}$ to $1.80 \mathrm{~m}$ with an annual decrease in groundwater level in the range of $0.02 \mathrm{~m}$ to $0.23 \mathrm{~m}$. The increase in groundwater level depth in monsoon seasons was found due to extreme usage in irrigation for rice crop and the recharging of aquifers is not speedy. However, it has also been observed that the groundwater level rises again in the post monsoon season due to the groundwater resilience of the aquifers. Besides this, the extensive recharge in the area is observed by Ravi and Beas rivers because of perennial nature.

The declining water level trends suggest that groundwater management must be taken seriously before declining water levels impact agricultural activity. It is essential to strengthen soil, water and groundwater institutions along with capacity building, training and education in specific areas like artificial recharge, groundwater modelling, watershed management, quality monitoring, and aquifer remediation on a continuous basis. Only with this increased capacity groundwater can be managed successfully and sustainably.

\section{Acknowledgement}

Authors thank Director, National Institute of Hydrology for all his support and encouragement for this study. The funding received from Purpose Driven Studies under HP-II and BGS-DFID is duly acknowledged. Authors thank Director (P.S. Bhogal) and Executive Engineer (J.P. Singh), Punjab Water Resources Environment Director, Chandigarh for allowing us to use their piezometers for taking the water level data. We also thank Alan MacDonald, Dan Lapworth and Helen Bonsor from BGS for their help with this research.

\section{References}

1. CGWB, Central Ground Water Board (2011) Dynamic Ground Water Resources of India, Ministry of Water Resources, Govt of India.

2. Chopra RPS, Krishan (2014). Analysis of aquifer characteristics and groundwater quality in southwest Punjab, India. J Earth Sci Clim Engg 4: 1-8.

3. Rodell M, Velicogna I, Famiglietti JS (2009) Satellite-based estimates of groundwater depletion in India. Nature 460: 999-1002.

4. Singh K (2011) Groundwater depletion in Punjab: measurement and countering strategies. Ind J Agric Econ 66: 573-590.

5. Sidhu RS, Vatta K, Dhaliwal HS (2010) Conservation agriculture in Punjab economic implications of technologies and practices. Ind J Agric Econ 65: 413427

6. CGWB, Central Ground Water Board (2007) Ground water scenario of Amritsar District, Punjab. Central Ground Water Board North Western Region, Chandigarh

7. CGWB. Central Ground Water Board (2007) Ground Information Booklet Tarn Taran District, Punjab. Central Ground Water Board North Western Region, Chandigarh.

8. CGWB. Central Ground Water Board (2008) Groundwater Information Booklet Gurdaspur District Punjab. Central Ground Water Board, North Western Region, Chandigarh.

9. Chopra RPS, Krishan G (2014) Assessment of groundwater quality in Punjab J Earth Sci Clim Change 5: 243.

10. Lapworth DJ, Krishan G, Rao MS, Alan M (2014) Impact of Groundwater Exploitation in the Mid Indo-Gangetic Basin: Implications for Future Trajectories of Groundwater Depletion and Water Quality. Project Report Groundwater Science Programme, BGS, UK (Unpublished)
11. Krishan G, Lohani AK, Rao MS, Kumar CP, Semwal P (2013) Optimization of groundwater monitoring network in Bist-Doab, Punjab. In: International Conference "India Water Week 2013-Efficient Water Management: Challenges and Opportunities" (IWW-2013)" 274, Delhi.

12. Krishan G, Rao MS, Kumar CP, Semwal P (2013). Identifying Salinization using Isotopes and lonchemistry in Semi-Arid Region of Punjab, India. J Geol Geosci 2:4

13. Krishan G, Rao MS, Loyal RS, Lohani AK, Tuli NK, et al. (2014) Octa Journal of Environmental Research. 2: 221-226.

14. Krishan G, Lapworth DJ, Rao MS, Kumar CP, Smilovic M, et al. (2014) Natural (Baseline) Groundwater Quality in the Bist-Doab Catchment, Punjab, India: A Pilot Study Comparing Shallow and Deep Aquifers. Int J Earth Sc Engg 7 : 16-26.

15. Krishan G, Lohani AK, Rao MS, Kumar CP (2014) Prioritization of groundwater monitoring sites using cross-correlation analysis. NDC-WWC Journal 3: 28-31.

16. Krishan G, Rao MS, Purushotaman P, Yawat Y S,Kumar CP, et al. (2014) Groundwater Resources in Bist-Doab region, Punjab, India-An overview. NDCWWC Journal. 3:5-13.

17. Lohani, A.K., Krishan, Gopal, Rao, M.S., Kumar, Sudhir. 2015. Groundwater Level Simulation Using Artificial Neural Network: A Case Study from Punjab India. In: Proceedings of an International conference "India Water Week 2015-Water Management for Sustainable Development" (IWW-2015), 13-17 January, 2015 at New Delhi, India 114.

18. Rao MS, Purushothaman P, Krishan G, Rawat YS, Kumar CP (2014) Hydrochemical and Isotopic Investigation of Groundwater Regime in Jalandhar and Kapurthala Districts, Punjab, India. Int J Earth Sc Engg, 7: 06-15

19. Valipour M (2012) A Comparison between Horizontal and Vertical Drainage Systems (Include Pipe Drainage, Open Ditch Drainage, and Pumped Wells) in Anisotropic Soils. Journal of Mechanical and Civil Engineering. 4: 7-12.

20. Valipour M (2012) Effect of Drainage Parameters Change on Amount of Drain Discharge in Subsurface Drainage Systems. Journal of Agriculture and Veterinary Science 1: 10-18.

21. Valipour M (2014) Drainage, Waterlogging and Salinity. Archives of Agronomy and Soil Science $60: 1625-1640$.

22. Suresh K, Krishan G, Saha SK (2008) Measuring soil salinity with WET sensor and characterization of salt affected soils. Agropedology. 18: 124-128.

23. Krishan G, Srivastav SK, Suresh K, Saha SK, Dadhwal VK (2009) Quantifying the underestimation of soil organic carbon by Walkley and Black technique- an example from Himalayan landscape and Central Indian soils. Current Science 96: 1133-1136.

24. Krishan G, Kushwaha SPS, Velmurugan A (2009) Land degradation mapping in upper catchment of river Tons. Journal of Indian Society of Remote Sensing 37: $119-128$.

25. Tripathi D, Raverkar KP, Krishan G (2005) Physico-chemical properties of some wasteland soils of Himachal Pradesh. Annals of Plant and Soil Research. 7:205-207.

26. Velmurugan A, Krishan G, Swarnam TP, Dadhwal VK, Suresh K et al. (2009) Harmonizing soil organic carbon estimates in historical and current data. Current Science 97: 554-558

27. Gallichand J (1994) Numerical simulations of steady-state subsurface drainage with vertically decreasing hydraulic conductivity. Irrigation and Drainage Systems 8: 1-12

28. Hunt B (2005) Flow to Vertical and Nonvertical Wells in Leaky Aquifers. Journal of Hydrologic Engineering 10: 477-484.

29. Census of India (2011) Provisional Population Totals : Punjab Data Sheet

30. Economic \& Statistical Organisation (2013) Statistical Abstract of Punjab, Government of Punjab. 